\title{
Genotype-environment interaction effects on weight gain in cattle using reaction
}

\section{norms}

\author{
Efeitos da interação genótipo-ambiente sobre o ganho de peso em bovinos usando normas de reação \\ Efectos de la interacción genotipo-ambiente en el aumento de peso del ganado vacuno mediante
} normas de reacción

Received: 09/30/2021 | Reviewed: 10/09/2021 | Accept: 10/11/2021| Published: 10/12/2021

\author{
Rafaela Zubler \\ ORCID: https://orcid.org/0000-0002-9273-0259 \\ Universidade Federal de Mato Grosso, Brazil \\ E-mail: rafaelazu@hotmail.com \\ Cláudio Vieira de Araújo \\ ORCID: https://orcid.org/0000-0001-9378-7348 \\ Universidade Federal de Mato Grosso, Brazil \\ E-mail: cvaufmt@gmail.com \\ Flávio Luiz de Menezes \\ ORCID: https://orcid.org/0000-0002-4009-9338 \\ Universidade Federal de Mato Grosso, Brazil \\ E-mail: flm.zootecnista@gmail.com \\ Rodrigo Reis Mota \\ ORCID: https://orcid.org/0000-0003-0566-3236 \\ University of Liège, Belgium \\ E-mail: rrmota@ulg.ac.be \\ Simone Inoe Araújo \\ ORCID: https://orcid.org/0000-0002-8125-6774 \\ Universidade Federal de Mato Grosso, Brazil \\ E-mail: araujoinoe@bol.com.br \\ Raysildo Barbosa Lôbo \\ ORCID: https://orcid.org/0000-0001-6016-5817 \\ National Association of Breeders and Researchers, Brazil \\ E-mail: raysildo@ancp.org.br \\ Lilian Roberta Matimoto Nakabashi \\ ORCID: https://orcid.org/0000-0002-5411-2177 \\ National Association of Breeders and Researchers, Brazil \\ E-mail: limatimoto@gmail.com
}

\begin{abstract}
The existence of genotype-environment interaction (GEI) using reaction norm models and their impact on the genetic evaluation of Nellore sires for body weight at 120, 210, 365 and 450 days of age was verified. Three models were used: animal model (AM) that disregards GEI and the one-step reaction norm model with homogeneous and heterogeneous residual variance (1SRNMH_het). Bayes Inference via Gibbs Sampling was used to estimate the variance components. The AM model better fits to weights at 120 and 210 days of age, while 1SRNMH_het was more adequate for body weights at 365 and 450 days of age, suggesting the existence of GEI. The posterior means of direct heritability were $0.33 \pm 0.01$ and $0.36 \pm 0.01$ and maternal heritability of $0.21 \pm 0.01$ and $0.19 \pm 0.01$ for body weights at 120 and 210 days of age, respectively. For body weights at 365 and 450 days of age, posterior means of heritability varied along the environmental gradient, but the ranking of sires based on breeding values was not changed by different environmental gradients. All rank correlations were greater than 0.80 , strongly suggesting a scale effect of GEI. Despite the evidence of GEI on post-weaning weight gain, it did not change the ranking of sires. Therefore, it did not have a relevant impact on the genetic evaluation of sires because they are robust to environmental changes.
\end{abstract}

Keywords: Bayesian analysis; Genetic parameters; Heterogeneity of variances; Performance.

\section{Resumo}

Objetivou-se verificar a existência da interação genótipo-ambiente (IGA) por meio de modelos de normas de reação e seu impacto na avaliação genética de reprodutores da raça Nelore para pesos corporais aos 120, 210, 365 e 450 dias de idade. Utilizaram-se três modelos: modelo animal tradicional (MA) considerando ausência da IGA e os modelos de normas de reação de um passo considerando variância residual homogênea e heterogênea (MHNR1p_het), utilizandose a inferência bayesiana, por meio de Amostrador de Gibbs para estimação dos componentes de variância. $\mathrm{O}$ modelo MA apresentou melhor ajuste para os pesos aos 120 e 210 dias de idade, enquanto que o MHNR1p_het foi mais 
adequado para os pesos corporais aos 365 e 450 dias de idade, caracterizando-se a presença de IGA. As médias posteriores de herdabilidade direta foram de $0,33 \pm 0,01$ e $0,36 \pm 0,01$ e maternas de $0,21 \pm 0,01$ e $0,19 \pm 0,01$ para os peso aos 120 e 210 dias de idade, respectivamente. Nos pesos corporais aos 365 e 450 dias de idade, as médias posteriores de herdabilidade variaram conforme o gradiente ambiental, porém, sem alteração no ordenamento dos valores genéticos dos reprodutores nos diferentes gradientes ambientais. Todas as correlações de ordem foram maiores que 0,80, enfatizando o efeito em escala da IGA. Assim, apesar de evidências de presença da IGA para o desempenho ponderal na fase de pós-desmame, a mesma não promoveu mudanças na classificação dos animais, portanto sem impacto relevante sobre a avaliação genética de reprodutores devido ao fato de que os mesmos são robustos frente às variações ambientais.

Palavras-chave: Análise bayesiana; Desempenho ponderal; Heterogeneidade de variâncias; Parâmetros genéticos.

\section{Resumen}

El objetivo fue verificar la existencia de la interacción genotipo-ambiente (IGA) mediante modelos de norma de reacción y su impacto en la evaluación genética de los toros de la raza Nelore para el peso corporal a los 120, 210, 365 y 450 días de edad. Se utilizaron tres modelos: el modelo animal tradicional (MA) considerando la ausencia de IGA y los modelos de normas de reacción de un paso considerando la varianza residual homogénea y heterogénea (MHNR1p_het), utilizando la inferencia bayesiana, a través del Gibbs Sampler para la estimación de los componentes de la varianza. El modelo MA presentó el mejor ajuste para los pesos a los 120 y 210 días de edad, mientras que el MHNR1p_het fue más apropiado para los pesos corporales a los 365 y 450 días de edad, caracterizando la presencia de IGA. Las medias posteriores de la heredabilidad directa fueron de $0,33 \pm 0,01$ y $0,36 \pm 0,01$ y la materna de $0,21 \pm 0,01$ y $0,19 \pm 0,01$ para los pesos corporales a los 120 y 210 días de edad, respectivamente. Para los pesos corporales a los 365 y 450 días de edad, las medias de heredabilidad posteriores variaron según el gradiente ambiental, sin embargo, sin que se alterara la ordenación de los valores genéticos de los toros en los distintos gradientes ambientales. Todas las correlaciones de orden fueron superiores a 0,80 , lo que pone de relieve el efecto de escala del IGA. Así, a pesar de la evidencia de la presencia de IGA para el rendimiento ponderal en la fase post-destete, no promovió cambios en la clasificación de los animales, por lo tanto sin impacto relevante en la evaluación genética de los sementales debido a que son robustos frente a las variaciones ambientales.

Palabras clave: Análisis bayesiano; Parámetros genéticos; Heterogeneidad de varianzas; Rendimiento.

\section{Introduction}

The selection of individuals in a given environment may not be valid to achieve the expected genetic gain in another environment, suggesting a possible influence of the genotype-environment interaction (GEI).

GEI occur when the genotype responds differently to changes in the environment (Kolmodin et al., 2002). The GEI may lead to changes in phenotypes, as well as changes in the absolute and relative magnitude of genetic and environmental variances. This implies that the performance of animals and their progeny can change according to the environmental conditions in which they are raised and selected (Mattar et al., 2011).

Therefore, the study of this interaction in beef cattle in Brazil is justified, since the production systems are relatively diversified due to the extensive area, with climatic, historical and cultural differences between regions(Oliveira et al. 2020).

Among the available methodologies for estimation of GEI, models of linear reaction norms have been widely used for gain traits (Souza et al. 2016; Ambrosini, 2016; Cardoso \& Tempelman, 2015 and Hay \& Roberts 2018).

The reaction norm $(\mathrm{RN})$ is defined as the set of phenotypes produced by a given genotype under different environments (De Jong, 1995). This methodology is based on curves of each genotype under two or more different environments, thus making it possible to establish the magnitude of GEI in the measured characteristic.

In these methodology, the environmental variable is considered to be continuous and can be defined by the proper dataset. Since genetic parameters are estimated on an environmental gradient, GEI can be identified more precisely based on the genetic correlations between different points on the environmental axis or by the non-parallelism in the estimates of adaptive reaction norms (Pégolo et al. 2009). Environment descriptors and data structure can influence these results, as shown by Fikse et al. (2003), Kolmodin et al. (2002) and Calus et al. (2002).

Pégolo et al. 2009 have demonstrated an important GEI in the 450-day weight trait of Nelore cattle analyzed by reaction norm models, leading to significant re-ranking of sires in different environments and show the need to consider GEI effects, not 
only in large scale (across countries), but also within a national analysis.

Considering the above, the aim of this study was to verify the existence of genotype-environment interaction effects on gain traits in Nellore herds from the Central-West region of Brazil using reaction norm models.

The objective of this paper was to evaluate the sensitivity of Nelore cattle to the environment by different models of reaction norms and to estimate the genetic progress in environmental gradient.

\section{Methodology}

The dataset consisted of 102,921 adjusted weights for 120,210, 365 and 450 days of age of Nellore beef cattle population from the Central-West region of Brazil, which participates in the genetic evaluation program of Associação Nacional de Criadores e Pesquisadores(ANCP), for animals born in 1990 to 2014.

To guarantee connectivity in the genetic evaluation, only sires with a minimum of four progenies in at least two different states were considered for analysis. The calving months were grouped into two seasons, corresponding to months of the lowest (from April to September) and highest (from October to March) rainfall levels and the contemporary groups (CG) were defined by using information on herd, year, gender, and calving season. CGs with less than four individuals were excluded.

Initially, we use a standard animal model (AM) that disregards GEI to estimate variances components and predict the animal's breeding value. For the body weight traits at 120 (W120) and at 210 (W210) days. The model was described as $\boldsymbol{y}=$ $X \boldsymbol{b}+Z_{1} \boldsymbol{a}+Z_{2} \boldsymbol{m}+Z_{3} \boldsymbol{p}+\boldsymbol{\varepsilon}$;, where $\mathbf{y}=$ vector of observations; $\boldsymbol{b}=$ vector of fixed effects (contemporary group and linear and quadratic for dam's age); $\boldsymbol{a}=$ vector of direct additive genetic effects; $\boldsymbol{m}=$ vector of maternal additive genetic effects; $\boldsymbol{p}=$ vector of maternal permanent environmental effects, and $\varepsilon=$ vector of residual random errors associated with observations. $X$, $Z_{1}, Z_{2}$ and $Z_{3}$ are incidence matrices related to $\boldsymbol{b}, \boldsymbol{a}, \boldsymbol{m}$ and $\boldsymbol{p}$ to $\boldsymbol{y}$.

Posteriorly, The one-step hierarchical reaction norm model (RNM) were implemented based on the unknown covariate proposition of Su et al. (2006). In the sense, the covariate was characterized by the CG effects that were jointly estimated with the RN of the animals.

The RNM used in the analyses is described as: $\mathbf{y}=\mathbf{X} \boldsymbol{\beta}+\mathbf{E h}+\mathbf{Z a}+\mathbf{H b}+\mathbf{e}$, where $\mathbf{y}=$ the vector of records of weights; $\boldsymbol{\beta}=$ the vector of fixed effects (linear and quadratic for dam's age); $\mathbf{h}=$ the vector of random CG effects; $\mathbf{a}$ and $\mathbf{b}=$ the vectors of random intercept and slope coefficients of animal additive genetic RN, respectively; $\mathbf{e}=$ the random error vectors; and $\mathbf{X}, \mathbf{E}$, $\mathbf{Z}$, and $\mathbf{H}=$ the incidence matrices. Once covariates associated with the RN are treated as unknown, each row of $\mathbf{H}$ has one nonzero element that is equal to the element $\mathbf{h}$ (contemporary group effect) associated with the corresponding record on $\mathbf{y}$, and all other elements of this row are equal to zero (Su et al., 2006).

Two different alternative assumptions were adopted for residual variance in the models, the first was Homoscedasticity of variance (RNMHO) with $\varepsilon \sim\left(0, \sigma^{2}\right)$ with $\sigma^{2}$ residual variance. The second assumption was heteroscedasticity of residual variance for reaction norm model (RNMHE), where $\mathbf{e} \sim \mathrm{N}\left(\mathbf{0}, \operatorname{diag}\left\{\sigma^{2}\left(n^{h j}\right)\right\}\right.$ wich each error term hasits specific residual variance as a function of the associated environmental covariate $h j$ ). This exponential function on a residual heteroskedasticity parameter, $n$, was based on the structural model proposed by Cardoso et al. (2005) and posterior means of $h j$ by the RNMHO model, $h j$, were used in the function to facilitate recognizable fully conditional posterior densities.

Bayesian inference was performed by Monte Carlo methods via Markov chains, using the GIBBS1F90 software (Misztal et al., 2014), which was run for a total of 500,000 iterations, after a burn-in period of 50,000 iterations. Samples were generated every 10 iterations (thin $=10$ ), resulting in a total of 45,000 effective samples for inference. The convergence was checked by Geweke's Z criterion (Geweeke, 1992)

To determine the best fitting model, the Deviance Information Criterion (DIC), conditional predictive ordinate (CPO) 
criterion and pseudo-Bayes factors (BF) were used. Further details about these criteria can be seen in Cardoso et al. (2005).

Heritability was estimated from the ratio of the genetic variance to the phenotypic variance (genetic and environmental), as follows: $h^{2} \mid X=\frac{\sigma_{a}^{2} \mid X}{\sigma_{a}^{2}\left|X+\sigma_{e}^{2}\right| X}$, where $\sigma_{e}^{2} \mid X=$ residual variance of environment $X$, obtained by $\sigma_{e}^{2} \mid X=\sigma_{e}^{2} \eta^{\prime} X$ in a heteroscedastic model and $\sigma_{e}^{2}$ in a homoscedastic model, in which $\eta=$ degree of heterogeneity of residual variance across environments (X). For the weights at 120 and 210 days, the maternal effect was also included to estimate the heritability.

Maternal heritability $\left(h_{m}^{2}\right)$,estimated only for weights at 120 and 210 days, was estimated from the ratio of the maternal effect variance $\left(\sigma_{m}^{2} \mid X\right)$ to the phenotypic variance (genetic and residual variance) + the maternal effect variance, as follows: $h_{m}^{2} \mid X=\frac{\sigma_{m}^{2} \mid X}{\sigma_{m}^{2}\left|X+\sigma_{a}^{2}\right| X+\sigma_{e}^{2} \mid X}$.

The correlation $\left(\hat{r}_{a, b}\right)$ between intercept (a) and slope (b) of reaction norms was obtained by dividing the covariance between a and $\mathrm{b}\left(\sigma_{a, b}\right)$ by the square root of their variances $\left(\sigma_{a}^{2} \sigma_{b}^{2}\right)$ :

$$
\hat{r}_{a, b}=\frac{\sigma_{a, b}}{\sqrt{\sigma_{a}^{2}} \sigma_{b}^{2}}
$$

The breeding value of animals $(\mathrm{G})$ was calculated by the sum between the intercept and the slope and the environmental gradient $(\mathrm{X})$, as: $\mathrm{G} \mid \mathrm{X}=\mathrm{a}+\mathrm{bX}$.

Subsequently, for each trait, the ranking of sires based on breeding values was plotted against the different environmental gradients. For this, only sires with a minimum of 10 progenies were considered.

The levels of environmental gradients were redefined as low, medium and high. The low gradient was in the first quartile, that is, the lowest $25 \%$ values of contemporary groups (averages of -12,744 for W365 and -27,6033 for W450). The medium gradient is defined as the environmental average, that is, $X=0$. The high gradient is composed of the highest $25 \%$ values of contemporary groups, that is, the third quartile (averages from 29.985 for W365 and 26.30 for W450).

For the evaluation of the genetic merits of sires with ten or more progenies for robustness and plasticity, a posterior mean for their slope was obtained, standardized and then classified as: Extremely robust (ER), with values within one standard deviation; Robust (R), with values greater than one and less than two standard deviations; Plastic (P), with values above and equal to two and less than three standard deviations; Extremely plastic (EP), with values equal to and above three standard deviations.

\section{Results}

The posterior means and standard deviations (SD), minimum and maximum values and number of records for body weights at 120 (W120), 210 (W210), 365 (W365) and 450 (W450) days of age are shown in Table 1. The coefficients of variation between body weights were similar: 0.16 for W120 and W210 and 0.18 for W365 and W450.

Table 1. Means, standard deviations (SD), minimum (Min) and maximum (Max) values, number of records (N) and contemporary groups (NCG) for body weights at 120 (W120), 210 (W210), 365 (W365) and 450 (W450) days of age.

\begin{tabular}{ccccccc}
\hline Body weight $(\mathrm{kg})$ & Mean & SD & Min & Max & N & NCG \\
\hline W120 & 127.15 & 19.98 & 52 & 214 & 86992 & 662 \\
W210 & 182.24 & 28.83 & 85 & 317 & 75047 & 651 \\
W365 & 232.10 & 42.23 & 101 & 444 & 60919 & 642 \\
W450 & 272.39 & 50.36 & 122 & 502 & 55390 & 596 \\
\hline
\end{tabular}




\section{Source: Authors.}

The Geweke's Z criterion, posterior means of additive genetic, residual and (co)variances components associated with covariance functions obtained using Markov chains are shown in Table 2. Geweke's Z criterion for all parameters of variance and covariance in the all models analyzed were less than 0.05 , were observed, these results showed that the sizes of the Markov chains were satisfactory for estimation of posterior means of variance components in the all models.

Table 2. Geweke scores $(\mathrm{Z})$ and their associated probabilities (p value) using different models for variance components (VC): genetic variance $(\sigma 2 \mathrm{~g})$, variance for the intercept of the reaction norm $(\sigma 2 \mathrm{a})$; variance for the slope of the reaction norm $(\sigma 2 \mathrm{~b})$; residual variance $(\sigma 2 \mathrm{e})$ for body weights at $120,210,365$ and 450 days of age.

\begin{tabular}{|c|c|c|c|c|c|}
\hline \multicolumn{6}{|c|}{ Body weight at 120 days (kg) } \\
\hline Model & Parameter & $\sigma^{2} \mathrm{~g}$ & $\sigma^{2} \mathrm{a}$ & $\sigma^{2} b$ & $\sigma^{2} \mathrm{e}$ \\
\hline \multirow{3}{*}{ AM_homo } & $\mathrm{VC}$ & $67.80 \pm 2.54$ & - & - & $139.05 \pm 1.63$ \\
\hline & $\mathrm{Z}$ (p value) & $0.41(0.68)$ & - & - & $-0.46(0.65)$ \\
\hline & $\mathrm{VC}$ & - & $57.49 \pm 7.66$ & $0.15 \pm 0.01$ & $130.42 \pm 3.24$ \\
\hline \multirow[t]{2}{*}{ 1SRNMH_homo } & $\mathrm{Z}$ (p value) & - & $-0.66(0.51)$ & $-1.66(0.09)$ & $0.72(0.47)$ \\
\hline & $\mathrm{VC}$ & - & $49.06 \pm 2.73$ & $0.31 \pm 0.02$ & $116.76 \pm 13.21$ \\
\hline 1SRNMH_het & $\mathrm{Z}$ (p value) & - & $-1.38(0.17)$ & $0.35(0.73)$ & $0.24(0.81)$ \\
\hline \multicolumn{6}{|c|}{ Body weight at 210 days (kg) } \\
\hline \multirow[t]{2}{*}{ Model } & Parameter & $\sigma^{2} g$ & $\sigma^{2} \mathrm{a}$ & $\sigma^{2} b$ & $\sigma^{2} \mathrm{e}$ \\
\hline & $\mathrm{VC}$ & $148.16 \pm 5.49$ & - & - & $262.88 \pm 3.48$ \\
\hline \multirow[t]{2}{*}{ AM_homo } & $\mathrm{Z}$ ( $\mathrm{p}$ value $)$ & $0.45(0.65)$ & - & - & $-0.42(0.67)$ \\
\hline & $\mathrm{VC}$ & - & $0.31 \pm 0.64$ & $0.07 \pm 0.004$ & $275.94 \pm 3.11$ \\
\hline \multirow[t]{2}{*}{ 1SRNMH_homo } & $\mathrm{Z}$ ( $\mathrm{p}$ value $)$ & - & $-1.79(0.07)$ & $1.3(0.19)$ & $-1.07(0.28)$ \\
\hline & $\mathrm{VC}$ & - & $134.90 \pm 5.85$ & $0.06 \pm 0.009$ & $247.80 \pm 10.31$ \\
\hline 1SRNMH_het & $\mathrm{Z}$ (p value) & - & $-0.67(0.50)$ & $-2.07(0.04)$ & $1.30(0.19)$ \\
\hline \multicolumn{6}{|c|}{ Body weight at 365 days (kg) } \\
\hline \multirow[t]{2}{*}{ Model } & Parameter & $\sigma^{2} \mathrm{~g}$ & $\sigma^{2} \mathrm{a}$ & $\sigma^{2} b$ & $\sigma^{2} \mathrm{e}$ \\
\hline & $\mathrm{VC}$ & $268.26 \pm 7.84$ & - & - & $370.72 \pm 5.63$ \\
\hline \multirow[t]{2}{*}{ AM_homo } & $\mathrm{Z}$ ( $\mathrm{p}$ value $)$ & $-1.05(0.29)$ & - & - & $1.21(0.23)$ \\
\hline & $\mathrm{VC}$ & - & $308.69 \pm 11.35$ & $0.05 \pm 0.003$ & $317.32 \pm 5.28$ \\
\hline \multirow[t]{2}{*}{ 1SRNMH_homo } & $\mathrm{Z}$ ( $\mathrm{p}$ value $)$ & - & $1.66(0.09)$ & $1.41(0.16)$ & $-1.55(0.12)$ \\
\hline & $\mathrm{VC}$ & - & $290.87 \pm 10.93$ & $0.05 \pm 0.005$ & $328.63 \pm 18.76$ \\
\hline 1SRNMH_het & $\mathrm{Z}$ (p value) & - & $-0.45(0.65)$ & $0.52(0.60)$ & $0.09(0.93)$ \\
\hline \multicolumn{6}{|c|}{ Body weight at 450 days $(\mathrm{kg})$} \\
\hline \multirow[t]{2}{*}{ Model } & Parameter & $\sigma^{2} g$ & $\sigma^{2} \mathrm{a}$ & $\sigma^{2} b$ & $\sigma^{2} \mathrm{e}$ \\
\hline & $\mathrm{VC}$ & $280.19 \pm 9.83$ & - & - & $430.46 \pm 7.14$ \\
\hline \multirow[t]{2}{*}{ AM_homo } & $\mathrm{Z}$ (p value) & $0.90(0.93)$ & - & - & $-0.95(0.34)$ \\
\hline & $\mathrm{VC}$ & - & $40.67 \pm 104.20$ & $0.03 \pm 0.002$ & $410.90 \pm 20.28$ \\
\hline \multirow[t]{2}{*}{ 1SRNMH_homo } & $\mathrm{Z}$ ( $\mathrm{p}$ value $)$ & - & $-0.67(0.50)$ & $1.82(0.07)$ & $1.11(0.27)$ \\
\hline & $\mathrm{VC}$ & - & $265.99 \pm 10.14$ & $0.05 \pm 0.003$ & $397.10 \pm 75.74$ \\
\hline 1SRNMH_het & $\mathrm{Z}$ ( $\mathrm{p}$ value $)$ & - & $-0.95(0.34)$ & $0.39(0.70)$ & $1.66(0.09)$ \\
\hline
\end{tabular}

Source: Authors.

According to the statistical criteria used (CPO: conditional predictive ordinate, DIC: Deviance Information Criterion, and BF: pseudo-Bayes factors), there were differences between models for pre- and post-weaning traits (Table 3). For the pre- 
weaning phase, the animal model (including a residual variance) was the most adequate based on the CPO and DIC criteria, while the reaction norm model with heterogeneous residual variance better fits to the data for the post-weaning phase.

Table 3. Conditional predictive ordinate (CPO) criterion, Deviance Information Criterion (DIC) and pseudo-Bayes factors (BF) using the animal model (AM) and reaction norm model (RNM) under assumptions of homogeneity (Homo) and heterogeneity (Het) of residual variances for pre- and post-weaning traits.

\begin{tabular}{|c|c|c|c|c|}
\hline & & AN & \multicolumn{2}{|c|}{ RNM } \\
\hline & & Homo & Homo & Het \\
\hline \multirow[t]{3}{*}{ W120 } & CPO & $724390.99^{(1)}$ & $731318.46^{(2)}$ & $768817.24^{(3)}$ \\
\hline & DIC & $848310.06^{(1)}$ & $853785.13^{(2)}$ & $1319374.27^{(3)}$ \\
\hline & $\mathrm{BF}$ & $673671.68^{(2)}$ & $685679.04^{(3)}$ & $656151.67^{(1)}$ \\
\hline \multirow[t]{3}{*}{ W210 } & $\mathrm{CPO}$ & $680741.04^{(1)}$ & $731318.46^{(3)}$ & $725710.03^{(2)}$ \\
\hline & DIC & $798480.86^{(1)}$ & $853785.13^{(2)}$ & $1285267.78^{(3)}$ \\
\hline & $\mathrm{BF}$ & $634615.13^{(2)}$ & $685679.04^{(3)}$ & 630191.33 $^{(1)}$ \\
\hline \multirow[t]{3}{*}{ W365 } & CPO & $570757.75^{(3)}$ & $568648.50^{(2)}$ & $561365.73^{(1)}$ \\
\hline & DIC & $672051.40^{(3)}$ & $663029.77^{(2)}$ & $572754.98^{(1)}$ \\
\hline & $\mathrm{BF}$ & $536529.84^{(3)}$ & $527323.36^{(1)}$ & $528277.27^{(2)}$ \\
\hline \multirow[t]{3}{*}{ W450 } & CPO & $520934.17^{(2)}$ & $524509.59^{(3)}$ & $514003.31^{(1)}$ \\
\hline & DIC & $572812.85^{(3)}$ & $-140012.7^{(1)}$ & $520785.68^{(2)}$ \\
\hline & $\mathrm{BF}$ & $496154.64^{(3)}$ & $494183.54^{(2)}$ & $486534.70^{(1)}$ \\
\hline
\end{tabular}

1, 2, 3: indicate the classification that best fits the data. Source: Authors.

Using the animal model, the posterior means of direct heritability for body weights at 120 and 210 days of age were $0.33 \pm 0.01$ and $0.36 \pm 0.01$, respectively. These values are below those found by De Lira et al. (2013) in Nellore herds raised in tropical humid region in Brazil, which were $0.37 \pm 0.02$ and $0.39 \pm 0.02$, respectively. However, higher values were found by Sena et al. (2013) in Nellore herds in the Legal Amazon, averaging 0.24 and 0.29 for W120 and W210, respectively.

The posterior means of direct maternal heritability for W120 and W210 were, respectively, $0.21 \pm 0.01$ and $0.19 \pm 0.01$, which are above the values found by De Lira et al. (2013), of $0.05 \pm 0.01$ and $0.06 \pm 0.01$. On the other hand, similar values were found by Sena et al. (2013), equal to 0.21 (W120) and 0.16 (W210).

The heritability estimates from the animal model (AM) and reaction norms (RN) for post-weaning traits are shown in Figure 1. The posterior means of heritability were $0.42 \pm 0.01$ and $0.39 \pm 0.01$ for W365 and W450, respectively, calculated from the AM. For RN, the estimates ranged from 0.39 to 0.80 for W365 and from 0.41 to 0.73 for W450. 
Figure 1. Heritability for W365 (A) and W450 (B) traits under different environmental gradients using the animal model (AM) and reaction norm model (RNM).

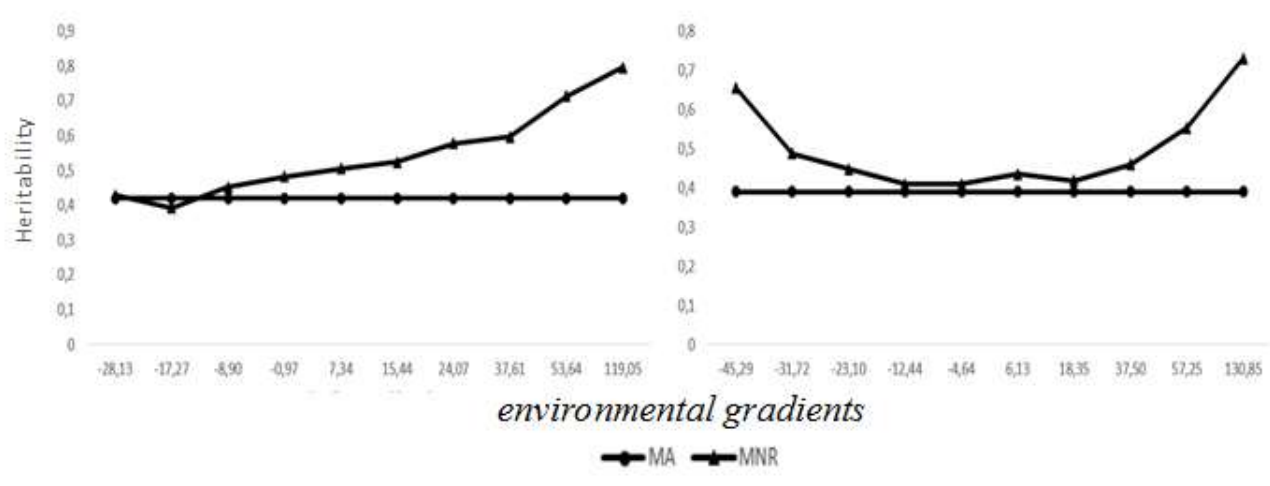

Source: Authors.

Estimates of posterior means of the additive genetic correlations between environmental gradients for post-weaning traits (Figures 2 and 3) showed that more similar environmental gradients (near) are more correlated, whereas more extreme gradients (distant) are less correlated. This indicates that most of the gene groups that express in similar environments are the same, which did not occurr between extreme environments. Consequently, for the same body weight that is expressed in contrasting environments, the additive gene action has different effects, suggesting an effect of the genotype-environment interaction.

Figure 2. Estimates of posterior means of the additive genetic correlations (corr) between environmental gradients (grad1 $\mathrm{x}$ $\operatorname{grad} 2)$ for body weight at 365 days (W365).

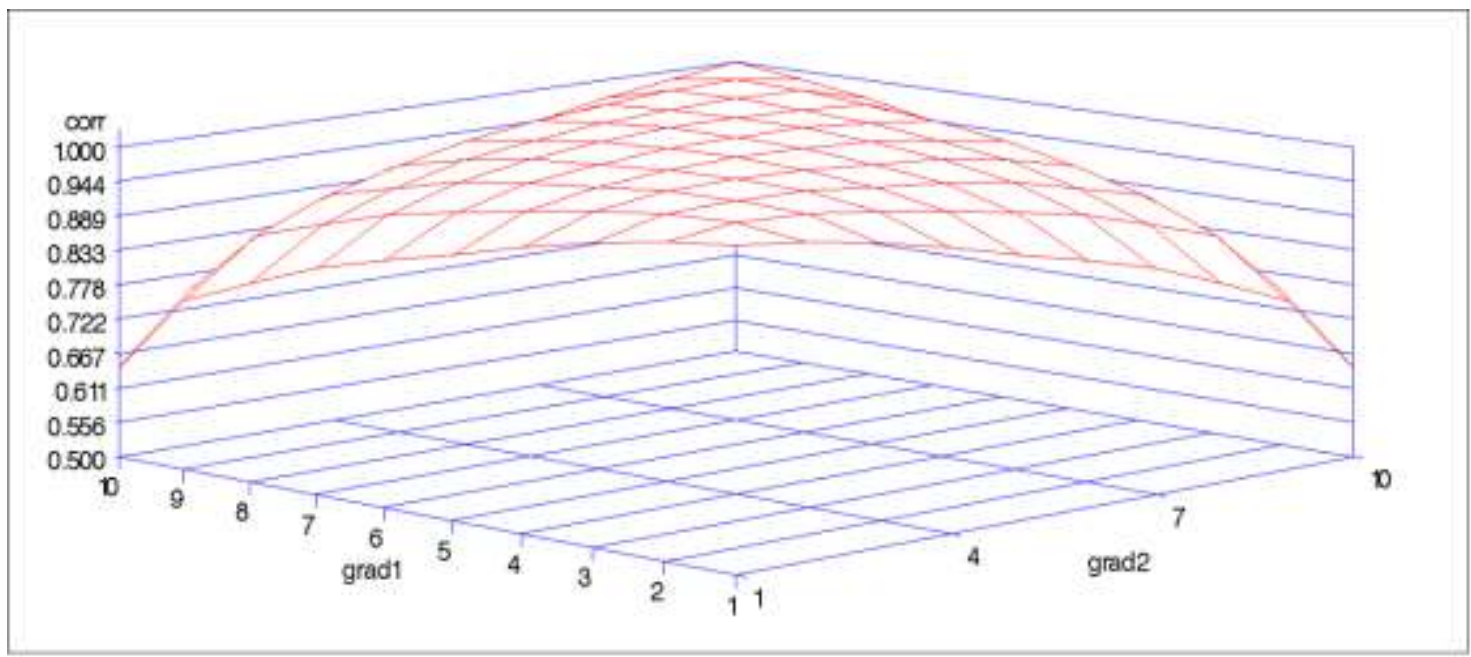

Source: Authors. 
Figure 3. Estimates of posterior means of the additive genetic correlations (corr) between environmental gradients (grad1 $\mathrm{x}$ $\operatorname{grad} 2$ ) for body weight at 450 days (W450).

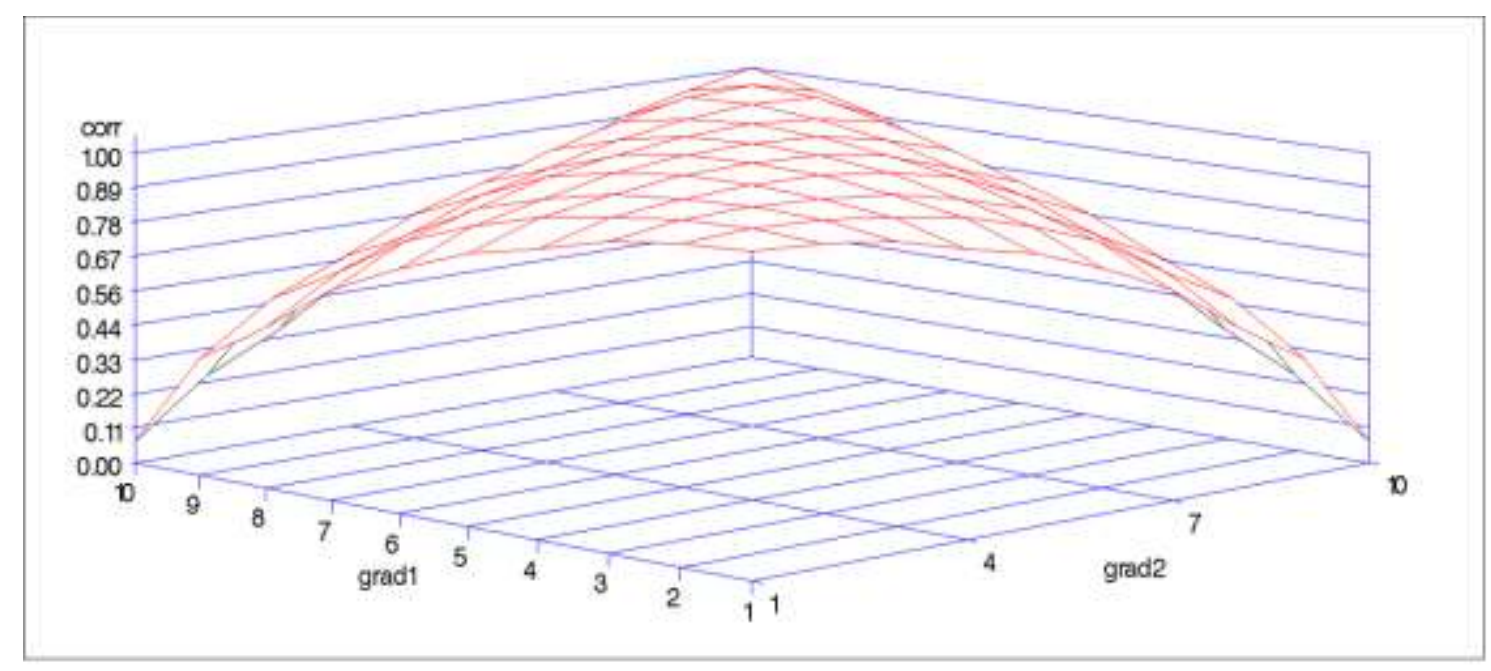

Source: Authors.

\section{Discussion}

The use of a covariance function in the model of reaction norms to describe the additive genetic variance for the environmental gradient levels did not fit well worked for W120 and W210. Thus, the criterias statistical CPO and DIC used pointed to the animal model as the most indicated for these characteristics, indicating absence of IGA for both traits. The fact that the animal model has met the criteria for good model performance may be related to the principle of parsimony, in which there is a occurrence to choose less parameterized models.

Howewer, the reaction norm model with heterogeneous residual variance was chosen for the estimation of GEI for W365 and W450. The existence of genotype-environment interaction effect on weight gain in post-weaning phase and absence in pre-weaning were verified.

This differs from Ambrosini et al. (2016), Souza et al. (2016) and Mattar et al. (2011), who evaluated Nellore, Tabapuã and Canchim breeds, respectively, in which the one-step reaction norm model with homogeneous residual variance was the bestfit model. However, the results found in the present study agree with other authors, who determined the residual heteroscedasticity for reaction norms in different species (Cardoso \& Tempelman, 2015 in Angus cattle, Knap \& Su, 2008 in swine, Pollott \& Greeff, 2004 in sheep and Calus et al., 2002 in dairy cattle).

Heritability estimates for W120 and W210 reveal the possibility of relevant genetic gains through selection for these body weights by additive gene action. Thus, for W120 and W210, considerable genetic gains are expected at weaning, as well as gains for maternal ability of progeny by the selection of the most positive sires.

Posterior means of heritability for W365 were $0.42 \pm 0.02 ; 0.47 \pm 0.02$ and $0.60 \pm 0.02$ in low, medium and high environmental gradients, respectively. Estimates for W450 were $0.37 \pm 0.05 ; 0.38 \pm 0.05$ and $0.44 \pm 0.05$ in low, medium and high environmental gradients, respectively. In general, all posterior means of heritability in both body weights and levels were high, revealing good responses to selection for these traits. However, more accurate responses to selection were found in more favorable environments. The increase of posterior means of heritability in relation to high environmental gradients agrees with other studies of growth traits in cattle (Mattar et al., 2011, Corrêa et al. 2009 and Santos et al. 2019). 
The correlations between the intercept and slope were $0.66 \pm 0.03$ and $0.24 \pm 0.04$ for W365 and W450, respectively. These values demonstrate that, not necessarily, sires with higher intercept values are also the most sensitive to environmental change.

For both W365 and W450, most of sires were classified as robust and extremely robust (representing more than 90\% for the two traits), that is, with a slope close to zero. This indicates that they respond similarly to different environments, consequently their breeding values are very similar even under contrasting environments.

The effects of the robustness of sires can also be seen in Table 5, in which the Spearman correlations between the AM and RNMH models were all significant $(\mathrm{P}<0.01)$, but of high magnitude even under extreme environments. Therefore, no change is expected in the ranking of sires evaluated under different environmental gradients classified as low, medium and high (RNM) compared to the traditional animal model (AM).

These results corroborate with Ambrosini et al. (2016), who also did not observe considerable changes in ranking of sires as most of them were robust. The results differ from Corrêa et al. (2009), who found negative correlations between extreme environments and Mattar et al. (2011), who found low correlations between extreme gradients. High values also indicate low magnitude of GEI, also reported by Cardoso et al. (2011).

The existence of a scale effect of GEI is verified, with changes in genetic parameters in different environmental gradients, but without changing the ranking of sires within them.

\section{Conclusion}

In this way, it is conclude that the existence of genotype-environment interaction effect on the body weight gain in Nellore herds from the Central-West region was verified in the post-weaning phase, but not in the pre-weaning phase. The reaction norm model with heterogeneous residual variance was the most adequate to describe the genotype-environment interaction for body weight in the post-weaning phase. In this sense, despite the evidence of genotype-environment interaction in the post-weaning phase, it did not change the ranking of sires. Therefore, it did not have a relevant impact on the genetic evaluation of sires because they are robust to environmental changes.

\section{Acknowledgments}

The authors wish to thank the Conselho Nacional de Desenvolvimento Científico e Tecnológico (CNPq) e a Associação Nacional de Criadores e Pesquisadores (ANCP) for providing support to this research.

\section{References}

Ambrosini, D. P., Malhado, C. H. M., Martins Filho, R. \& Carneiro, P. L. S. (2016) Interação genótipo x ambiente via modelos de normas de reação para características de crescimento em bovinos Nelore. Pesquisa Agropecuária Brasileira, 51, 177-186. https://doi.org/10.1590/S0100-204X2016000200010.

Calus, M. P. L., Groen, A. F. \& De Jong, G. (2002) Genotype x environment interaction for protein yield in Dutch dairy cattle as quantified by different models. Journal of Dairy Science, 85,3115-3123. https://doi.org/10.3168/jds.S0022-0302(02)74399-3.

Cardoso, F. F. \& Tempelman, R. J. (2015) Linear reaction norm models for genetic merit perdiction of Angus cattle under genotype by environment interaction. Journal of Animal Science, Cambridge 90, 2130-2141. https://doi.org/10.2527/jas.2011-4333.

Cardoso, L. L., Neto, J. B., Cardodo, F. F., Cobucci, J. A., Biassus, I. O. \& Barcellos, J. O. J. (2011) Hierarchical Bayesian models for genotype-environment estimates in post-weaning gain of Hereford bovine via reaction norms. Revista Brasileira de Zootecnia, 40, 294-300. 10.1590/S1516-35982011000200009.

Corrêa, M. B. B., Dionello, N. J. L. \& Cardoso, F. F. (2009) Caracterização da interação genótipo-ambiente e comparação entre modelos para ajuste do ganho pós-desmama de bovinos Devon via normas de reação. Revista Brasileira de Zootecnia, 38, 1468-1477. https://doi.org/10.1590/S1516-35982009000800010.

De Lira, T. S., Pereira, L. S., Lopes, F. B., Ferreira, J. L., Lôbo, R. B. \& Santos, G. C. J. (2013) Tendências genéticas para características de crescimento em rebanhos Nelore criados na região do Trópico Úmido do Brasil. Ciência Animal Brasileira, 14, 23-31. https://doi.org/10.5216/cab.v14i1.16785. 
Research, Society and Development, v. 10, n. 13, e278101321244, 2021

(CC BY 4.0) | ISSN 2525-3409 | DOI: http://dx.doi.org/10.33448/rsd-v10i13.21244

Fikse W. F., Rekaya, R. \& Weigel, K. A. (2003) Assessment of environmental descriptors for studying genotype by environment interaction. Livestock Production Science, 82, 223-231. https://doi.org/10.1016/S0301-6226(03)00009-5.

Geweeke (1992). Evaluating the accuracy of sampling-based approaches to the calculation of posterior moments . In Bernado, J. M., Berger, J. B, Dawid, A. P. \& Smitih, J. F. M. (eds.), Bayesian Statistics 4, pp. 69-193, Oxford: Oxford University Press,

Hay, E. H., \& Roberts, A. (2018). Genotypex prenatal and post-weaning nutritional environment interaction in a composite beef cattle breed using reaction norms and a multi-trait model. Journal of animal science, 96-2, 444-453. https://doi.org/10.1093/jas/skx057.

Knap, P. W. \& Su, G. (2008) Genotype by environment interaction for little size in pigs as quantified by reaction norms analysis. Animal, 2,1742-1747. doi: $10.1017 /$ S1751731108003145.

Kolmodin R, Str\&berg E, Madsen P, Jensen J \& Jordani H (2002) Genotype by environment interaction in Nordic dairy cattle studied using reaction norms. Acta Agriculturae Sc \&inavica, Section A-Animal Science, 52,11-24. https://doi.org/10.1080/09064700252806380.

Mattar, M. Silva, L. O. C., Alencar, M. M. \& Cardoso, F. F. (2011) Genotype x environment interaction for long-yearling weight in Canchim cattle quantified by reaction norm analysis. Journal of Animal Science, 89, 2349-2355. https://doi.org/10.2527/jas.2010-3770.

Oliveira, P. H. L., Nunes, D., de Andrade, A. S., Junior, J. G., \& Silva, L. S. (2020). Estudo da heterogeneidade de variâncias na avaliação genética para o peso corporal aos 450 dias de idade em animais da raça Nelore. Brazilian Journal of Development, 6(10), 79773-79788. https://doi.org/10.34117/bjdv6n10-415.

Pollott, G. E. \& Greffeff, J. C. (2004) Genotype x environment interactions \& genetic parameters for fecal egg count \& production traits of Merino sheep. Journal of Animal Science, 82, 2840-2851. https://doi.org/10.2527/2004.82102840x.

Santos, J., Malhado, C. H., Ambrosini, D., Araujo, A., \& Carneiro, P. L. (2019). Normas de reação para peso aos 365 e 550 dias de idade em bovinos Guzerá no Nordeste do Brasil. Archivos de zootecnia, 68, 562-570. https://doi.org/10.21071/az.v68i264.4996.

Sena, J. S. S., Matos, A. S., Marcondes, C. R., Bezerra, L. A. F. \& Lôbo, R. B. (2013) Parâmetros genéticos, tendências e resposta à seleção de características produtivas da raça Nelore na Amazônia Legal. Atlas de saúde ambiental 1, 2-12.

Souza, L. de A., Malhado, M. C. H., Braccini, J. N., Martins, R. F. \& Carneiro, P. L. S. (2016) Genotype-environment interactions on the weight of Tabapua cattle in the northeast of Brazil. Revista Caatinga 29, 206-215. https://doi.org/10.1590/1983-21252016v29n124rc. 